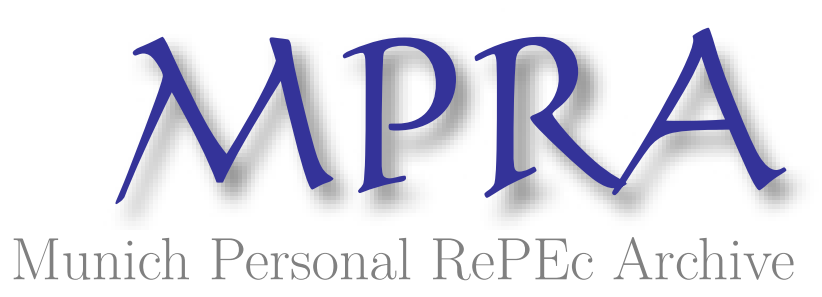

\title{
The Financing Dilemma Supporting a Project
}

\author{
Mullat, Joseph
}

Former docent, Department of Economics, Tallinn Technical University $(1973-1980)$.

11 November 2019

Online at https://mpra.ub.uni-muenchen.de/96879/

MPRA Paper No. 96879, posted 23 Nov 2019 00:38 UTC 


\title{
The Financing Dilemma Supporting a Project
}

\author{
J. E. Mullat ${ }^{*}$ Credits: **
}

Copenhagen, Denmark, mailto: mjoosep@gmail.com

\begin{abstract}
A concept of a kernel was re-visited for coalition formation in a game of interconnected participants characterized by monotonic contribution functions. We focused on special coalitions that have an advantage over the remaining, due to yielding higher contribution of each individual participant.

Keywords: coalition, game, contribution, donation, monotonic, project JEL Classification: C50, C53, C71
\end{abstract}

In multi-person games (Owen 1971, 1982) a coalition is formed by a subset of participants. Among all coalitions, rational coalitions are of particular interest, as these allow all participants to gain individual benefits. It can further be stipulated that extraction of this benefit is ensured independently of the actions of players that are not coalition members. In this note, we will deal with one of the simplest cases of player-formed coalitions, all of which can be considered as "outstanding" in terms of bounded rationality. Bounded rationality is the idea that rational decision making of people is limited by people's irrational nature.

The class of games proposed is subjected to an additional monotonic condition, which has been studied in previous work of Mullat 1979. However, it should be noted that no prior knowledge of the subject matter discussed here is presupposed. Still, the formal theory of monotone systems adopted in this note is identical to that described earlier by Mullat 19711977; the only difference arises in interpretation, and pertains to the ab-

Former docent, Department of Economics, Tallinn Technical University (1973 - 1980).

** Communicated with E.Н. Кузнецов, Институт проблем управления им. В.А.

Трапезникова РАН Россия, 117997, Москва, Профсоюзная ул., 65. Previous work in "Stable Coalitions in Monotonic Games", Avt.. i Tel., No. 10, pp. 84 - 94, October, 1979. Original article submitted October 3, 1978. Plenum Publishing Corporation, 227 West 17th Street, New York, 10011., http://www.datalaundering.com/download/monogame-ru.pdf, Russian version. We alert the readers' obligation with respect to copyrighted material. 


\section{The concept of kernel}

stract indices of interconnection of the system elements, which are treated as donation intentions. The approach developed in this note enables us to establish, in one particular case, the possibility of finding rational coalitions in accordance with the principle of independence of rejected alternatives according to Nash 1950. However, for the purpose of simplicity, the following scenario might be informative.

\section{Pedagogical scenario}

Here we are dealing with participants who intend to finance a specific project by providing donations. Each participant, in principle, is ready to donate a certain amount in favor of the project being developed. It is assumed that the donation amount $p_{i}$ for each participant $i=\overline{1, n}$ must correspond to some distribution defined by the exponential density function:

$$
f(x, \beta)=\left\{\begin{array}{l}
\frac{1}{\beta} \cdot \exp (-x / \beta) \text { for } x \geq 0 \\
0 \text { for } x<0
\end{array} .\right.
$$

Thus, in favor of the project it is expected to collect a certain fund to finance the project. However, as a result of negotiations about the appropriateness of the planned project with like-minded participants, their preferences will be reoriented. It is assumed that a certain coalition game arises here in accordance with the monotonic game scheme, the solution of which is the concept of a kernel, Mullat 1979. The kernel is a somewhat remarkable subset of the participants.

Intricacies of financing interests of the participants are presented in the form of a solution called, as said, the kernel, that will constitute a certain group of participants who agree to finance the project, but perhaps not to the extent to which they were originally intended, but still within reasonable limits. In fact, this reasonable limit is the best of all possible options for financing the project in its final version. It should be noted here that the best option is understood as a certain guaranteed payment at which each kernel participant guarantees contribution to the total amount. For 
the participant $\mathrm{j} \in \mathrm{H}^{*}$ belonging to the kernel $\mathrm{H}^{*}$, the guaranteed payment will be equal to $F\left(H^{*}\right)=\min _{j \in H^{*}} \frac{\left|H^{*}\right|}{n} \cdot p_{j}$. Thus, the total guaranteed payment constitutes $\left|\mathrm{H}^{*}\right| \cdot \mathrm{F}\left(\mathrm{H}^{*}\right)$. Nevertheless, the question may arise whether this total payment will be the largest of all possible options. It is, however, conceivable that a larger number of participants with a lower guaranteed payment intentions will be able to fund the project to a greater extent than the kernel participants. The kernel, on the other hand, is remarkable. Indeed

$$
\mathrm{H}^{*}=\arg \max _{\mathrm{X} \subseteq \mathrm{W}} \mathrm{F}(\mathrm{X}) .
$$

The global maximum for the project funding by the kernel participants will form the basis of independence in accordance with the hypothesis of the so-called rejected alternatives, that is, regardless of the preferences of the participants not included in the kernel, if any are found, which nevertheless consider it appropriate to participate in the kernel. But we should not particularly believe them, as they will not be very reliable, and may seek to change their preferences not in favor of the project.

Therefore, we assume that non-kernel participants refusing to participate in the project will not affect those who belong to the kernel, i.e., the views and activities of the kernel members. Here we are dealing, as said, with the so-called principle of bounded rationality, that is, the principle of independence from rejected alternatives, cf. Nash 1950. In essence, this principle in our particular case of project financing, ensures that project participants are kept abreast of developments. The kernel participants will not change their decisions on financing regardless of what is happening or what change the conditions for participation in the project, despite the fact that some participants in the project refused to participate. If we give this last consideration a somewhat more formal character, then we can say that the stability property of decisions made by the kernel participants is nothing but the well-known so-called idempotent principle. After the decision 


\section{The concept of kernel}

is revised in the conditions when the commitments and priorities assumed remain unchanged, it will not require any new adjustments, and this decision will be made in the same form in which it was adopted earlier.

Example. Let we introduce in accord with exponential distribution the preferences $\mathrm{p}_{\mathrm{i}}, \mathrm{i}=\overline{1, \mathrm{n}}$, of participants' $\mathrm{W}=\{\mathrm{i}=\overline{1, n}\}$. We can designate as $\mathrm{X}$ all participants who prefer to participate in the project together with their like-minded people, while $\bar{X}$ prefer to reject the project or have other reasons for participating in the project.

Let we now try to determine the preferences $\pi$ for the participants $j$ in $X, j \in X$, supposing that their contributions in the project together with others in $X$ be equal to $\pi(j, X)=(|X| / n) \cdot p_{j}$. Obviously, if some participant could not at all to find a suitable partner for the project, the intention to contribute will be equal to $\pi(\mathrm{i},\{\mathrm{i}\})=|\{\mathrm{i}\}|=1 / \mathrm{n} \cdot \mathrm{p}_{\mathrm{i}}$. Conversely, if all participants contribute to the project and all participants are in an adequate company $\mathrm{W}$, the estimated contribution will be greater and equal to $\pi(\mathrm{i}, \mathrm{W})={ }^{|\mathrm{W}|=\mathrm{n}} \mathrm{n} \cdot \mathrm{p}_{\mathrm{i}}$. If now for any reason a participant $\mathrm{j} \in \mathrm{X}$ decides to spend the rest of the project development alone, the intention to contribute to all others remaining participants in $\mathrm{X}$, including those to which some like-minded participants $\mathrm{X}-\{\mathrm{j}\}$ still join, will decrease: $\pi(\mathrm{i}, \mathrm{X}-\{\mathrm{j}\}) \leq \pi(\mathrm{i}, \mathrm{X})$ for $\mathrm{i} \in \mathrm{X}-\{\mathrm{j}\}$. On the contrary, their intentions to contribute will increase if one $\mathrm{j} \in \overline{\mathrm{X}}$ of the previously single participants decides to join $\mathrm{X}$ and become a member of $\mathrm{X}+\{\mathrm{j}\}: \pi(\mathrm{i}, \mathrm{X}+\{\mathrm{j}\}) \geq \pi(\mathrm{i}, \mathrm{X})$ for $i \in X$.

The graph below shows the donations of the participants in $\%$ relative to the total amount of their initial intentions on the X-axis with the corresponding contributions in $\%$, as well as to the same amount indicated on the Y-axis, where their donation preferences were reoriented. As the simulation shows, kernel members are almost always ready to finance approx. $50 \%$ of their original intentions. 


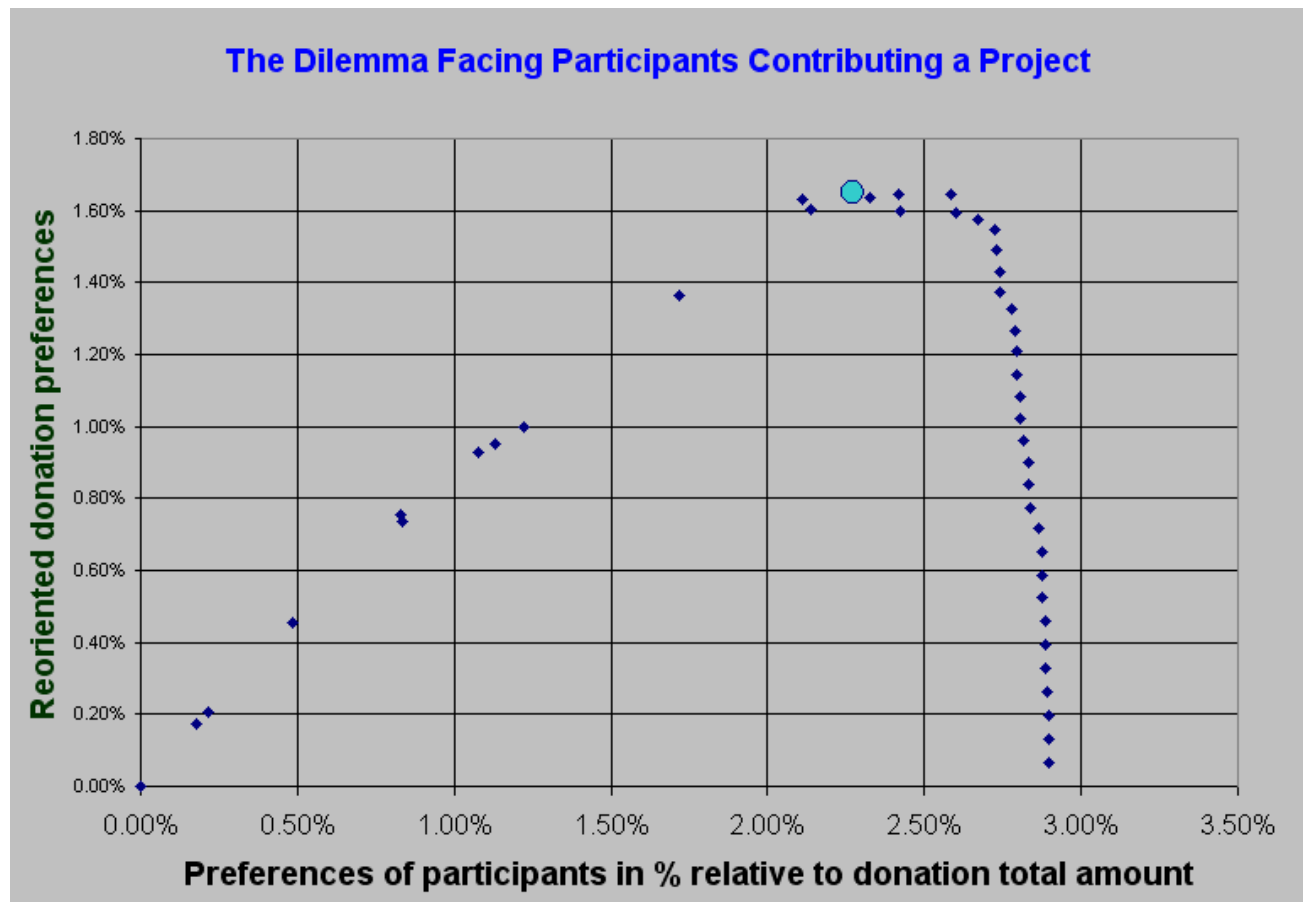

Figure 1. The kernel participants contribute at least $52.8 \%$ of their initial intentions to the project. The blue dot is the largest guaranteed contribution in which participants continue to agree to participate in the project.

To be more precise, in the initial state, the percentage of contribution to the total amount for financing the project, which reflects, as it was, the starting point of the participants' preferences on the $\mathrm{X}$ axis-donation submission of participants.

The procedure for finding the kernel is very easy to set up. First, all the expected donation preferences $p_{i}, i=\overline{1, n}$, are sorted in ascending order, constituting the order $\left.p_{j}\right), j=\overline{1, n}$, the $X$-axis, and then a sequence $\pi_{j}$ is constructed as $\pi_{j}=\left\langle p_{j}\right\rangle \frac{(n+1-j)}{n}$, which we have already denoted these reoriented $\pi_{\mathrm{j}}$ preferences, $\mathrm{j}=\overline{1, \mathrm{n}}$, the $\mathrm{Y}$-axis. The latter sequence is called defining. We then select the local maximum, i.e. the defining sequence. This is the kernel of Mullat's monotonic game, which is represented by a blue dot in Figure 1. 
The concept of kernel

\section{Finanseerimise Dilemma Projekti Toetamisel}

Kokkuvõtte. Tuuma mõistet külastati uuesti koalitsiooni moodustamiseks proekti financeerimise mängus, mida iseloomustavad monotoonsed panusefunktsioonid. Keskendusime spetsiaalsetele koalitsioonidele, millel on eelis ülejäänud osas, kuna iga osalemine koalitsioonis annab suurema panuse.

Mitme-isiku mängudes (Owen 1971, 1982) moodustatakse koalitsioon osalejate alamrühmast. Kõigist koalitsioonidest pakuvad ratsionaalsed koalitsioonid eriti huvi, kuna need võimaldavad kõigil osalejatel saada individuaalseid eeliseid. Veel võib täpsustada, et selle hüvitise saamine tagatakse sõltumata mängijate tegevusest, kes ei ole koalitsiooni liikmed. Selles märkuses käsitleme mängijate poolt moodustatud koalitsioonide ühte kõige lihtsamat juhtumit, mida võib pidada piiratud ratsionnaalsuse mõttes silmapaistvateks. Ratsionaalsus on piiratud sellega, et inimeste ratsionaalset otsustamist piirab inimeste irratsionaalne olemus.

Pakutud mängude klassile rakendatakse täiendavat monotoonset seisundit, mida on uuritud Mullati poolt 1979 aasta varasemas töös. Tuleb märkida, et siin käsitletud teema eelteadmisi ei eeldata. Kasutatud monotoonsete süsteemide teooria on identne sellega, mida on varem kirjeldanud, Mullat 1971-1977; ainus erinevus ilmneb tõlgendamises ja puudutab süsteemielementide abstraktseid sidumisnäitajaid, mida käsitletakse annetuste kavatsustena. Selles märkuses välja töötatud lähenemisviis võimaldab meil ühel konkreetsel juhul luua võimaluse ratsionaalsete koalitsioonide leidmiseks kooskõlas Nash'i 1950 vastavate tagasilükatud alternatiivide sõltumatuse põhimõttega. Lihtsuse huvides järgmine stsenaarium võib aga olla informatiivne.

\section{Pedagogika}

Siin on tegemist osalejatega, kes kavatsevad annetuste kaudu rahastada konkreetset projekti. Põhimõtteliselt on iga osaleja $i=\overline{1, n}$ valmis annetama arendatava projekti heaks teatud summa $\mathrm{p}_{\mathrm{i}}$. Kokkuvõtlikult võib öelda, et iga osaleja annetussumma peab vastama teatud jaotusele, mis on määratletud eksponentsiaalse tiheduse funktsiooniga: 


$$
f(x, \beta)=\left\{\begin{array}{l}
\frac{1}{\beta} \cdot \exp (-x / \beta) \text { for } x \geq 0 \\
0 \text { for } x<0
\end{array} .\right.
$$

Seega loodetakse projekti kasuks koguda teatav fond projekti rahastamiseks. Kuid mõttekaaslastega kavandatava projekti sobivuse üle peetavate läbirääkimiste tulemusel suunatakse nende eelistused ümber. Eeldatakse, et siin tekib teatud koalitsioonimäng vastavalt monotoonsele mänguskeemile, mille lahenduseks on tuuma mõiste, Mullat 1979. Tuum on osalejate mõnevõrra tähelepanuväärne alamhulk.

Nagu juba ööldud on osalejate finantseerimishuvide keerukus esitatud lahenduse vormis, mida nimetatakse tuumaks, mis moodustab teatud osalejate rühma, kes nõustuvad projekti rahastama, kuid võib-olla mitte sellises mahus, nagu need algselt olid mõeldud, kuid siiski mõistlikkuse piires. Tegelikult on see mõistlik piir parim võimalikest projekti lõppfinantseerimisvõimaluste rahastamise võimalustest. Siinkohal tuleb märkida, et parimaks võimaluseks loetakse kindlat garanteeritud makset, mille korral iga tuuma osaleja tagab panuse kogusummas. Tuuma $\mathrm{H}^{*}$ kuuluva osaleja $\mathrm{j} \in \mathrm{H}^{*}$ korral on tagatud makse võrdne $\mathrm{F}\left(\mathrm{H}^{*}\right)=\min _{\mathrm{j} \in \mathrm{H}^{*}}\left|\mathrm{H}^{*}\right| / \mathrm{n} \cdot \mathrm{p}_{\mathrm{j}}-$ ga. Seega moodustab kogu tagatud makse $\left|\mathrm{H}^{*}\right| \cdot \mathrm{F}\left(\mathrm{H}^{*}\right)$. Sellegipoolest võib tekkida küsimus, kas see kogusumma on kõigist võimalikest suurim. Siiski on mõeldav, et mingi suurem arv madalama garanteeritud maksekavatsusega osalejaid suudab projekti suuremal määral rahastada kui tuuma osalised. Tuum seevastu on tähelepanuväärne. Tõepoolest

$$
\mathrm{H}^{*}=\arg \max _{\mathrm{X} \subseteq \mathrm{W}} \mathrm{F}(\mathrm{X}) \text {. }
$$

Tuuma poolt projektile eraldatav globaalse maksimumi kogurahastus moodustab sõltumatuse aluse vastavalt nn tagasilükatud alternatiivide hüpoteesile, st sõltumata tuuma mittekuuluvate osalejate eelistustest, kui neid leidub, mis peavad tuumas osalemist siiski asjakohaseks. Kuid me ei tohiks eriti neid uskuda, kuna need ei ole väga usaldusväärsed ja võib-olla soovivad nad oma eelistusi projektis osalemise kohta muuta. 
The concept of kernel

Seetõttu eeldame, et kui tuuma mittekuuluvad osalejad keelduvad projektis osalemast, siis ei mõjuta see neid kes kuuluvad tuuma, st tuumaliikmete vaateid ja nende tegevusi. Siin on tegemist nagu juba ööldud, niinimetatud piiratud ratsionaalsuse põhimõttega, see tähendab sõltumatuse põhimõttega tagasilükatud alternatiividest, vrd. Nash 1950. Sisuliselt tagab see põhimõte meie konkreetse projekti rahastamise puhul, et projektis osalejad oleksid arengutega kursis. Tuuma osalejad ei muuda oma rahastamisotsuseid olenemata sellest, mis toimub või mis muudavad projektis osalemise tingimusi, hoolimata asjaolust, et mõned projektis osalejad keeldusid osalemast. Kui anname sellele viimasele kaalutlusele mõnevõrra formaalsema iseloomu, siis võime öelda, et tuumast osavõtjate tehtud otsuste stabiilsuse omadus pole midagi muud kui tuntud idempotentsuse põhimõte. Pärast otsuse läbivaatamist tingimustes, kus võetud kohustused ja prioriteedid jäävad muutumatuks, ei vaja see uusi muudatusi ning see otsus tehakse samal kujul, nagu see varem vastu võeti.

Näide. Tutvustame vastavalt eksponentsiaalsele jaotusele osalejate $\mathrm{W}=\{\mathrm{i}=\overline{1, n}\}$ eelistusi $\mathrm{p}_{\mathrm{i}}, \mathrm{i}=\overline{1, \mathrm{n}}$. Võime $\mathrm{X}$-na tähistada kõiki osalejaid, kes eelistavad projektis osaleda, et koos oma mõttekaaslastega kokku leppida, samal ajal kui $\overline{\mathrm{X}}$-s olevad osalejad eelistavad projekti tagasi lükata või on neil muud põhjused projektis osalemiseks.

Proovime nüüd määrata kindlaks $X$-s osalejate $j \in X$ eelistused, eeldades, et nende panus projekti koos teistega $X-s$ on võrdne $\pi(\mathrm{j}, \mathrm{X})=(|\mathrm{X}| \mathrm{n}) \cdot \mathrm{p}_{\mathrm{j}}$. Ilmselt kui mõni osaleja ei suuda üldse projekti jaoks sobivat partnerit leida, on kaastöö tegemise kavatsus võrdne $\pi(\mathrm{i},\{\mathrm{i}\})=|\{i\}|=1 / \mathrm{n} \cdot \mathrm{p}_{\mathrm{i}}$-ga. Ja vastupidi, kui kõik osalejad panustavad projekti ja kõik osalejad on sobivas mõttekaaslaste seas $W$, on nende viimaste eeldatav panus suurem ja võrdne $\pi(\mathrm{i}, \mathrm{W})={ }^{|\mathrm{w}|=\mathrm{n}} / \mathrm{n} \cdot \mathrm{p}_{\mathrm{i}}$-iga. Kui nüüd mõni osaleja $\mathrm{j} \in \mathrm{X}$ soovib või otsustab mingil põhjusel veeta ülejäänud projekti arenduse üksi, väheneb kavatsus panustama kõigile teistele $X$-is allesjäänud osalejatele, sealhulgas ka neile, kellega mõned mõttekaaslased X-ga endiselt liituvad: $\mathrm{i} \in \mathrm{X}-\{\mathrm{j}\}, \pi(\mathrm{i}, \mathrm{X}-\{\mathrm{j}\}) \leq \pi(\mathrm{i}, \mathrm{X})$. Vastupidi, nende panustamiskavatsused suurenevad, kui üks varem osalenud üksikliikmeline $\mathrm{j} \in \overline{\mathrm{X}}$ osaleja otsustab liituda $\mathrm{X}$-iga ja saada $\mathrm{X}+\{\mathrm{j}\}$ liikmeks: $\pi(\mathrm{i}, \mathrm{X}+\{\mathrm{j}\}) \geq \pi(\mathrm{i}, \mathrm{X})$. 
Ülaloleval joonisel, Figure 1, on näidatud osalejate annetused protsentides, võrreldes nende esialgsete kavatsuste suhtes kogusumma panusena X-teljel koos vastava sissemaksega protsentides, samuti sama summa kohta, mis on näidatud Y-teljel, kus nende annetuseelistused olid ümber orienteeritud. Nagu simulatsioon näitab, on tuuma liikmed peaaegu alati valmis finantseerima umbes. 50\% nende algsest kavatsusest. Kui täpsem olla, siis algseisundis on projekti finantseerimise kogusummast tehtud panuse protsent, mis peegeldab osalejate eelistuste lähtepunkti X-teljelosalejate annetuste esitamine.

Tuuma $\mathrm{H}^{*}$ leidmise protseduuri on väga lihtne üles ehitada. Esiteks järjestatakse kõik arvud $p_{i}, i=\overline{1, n}$, kasvavas järjekorras, muutes järjestust $p_{i}$ järjestuseks $\left\langle\mathrm{p}_{\mathrm{j}}, \mathrm{j}=\overline{1, \mathrm{n}}\right.$, ja seejärel konstrueeritakse järgmiste arvude jada, mida me nagu eelpool juba neid arvu tähistanud olime $\pi_{\mathrm{j}}-\mathrm{ks}$ : $\mathrm{j}=\overline{1, \mathrm{n}}, \pi_{\mathrm{j}}=\left\langle\mathrm{p}_{\mathrm{j}} \frac{(\mathrm{n}+1-\mathrm{j})}{\mathrm{n}}\right.$ mis on Joonise 1 Y-teljel, nn osalejate panuste ümberorienteerimine. Seda jada nimetatakse määravaks jadaks. Seejärel valime selle viimase, järjestatud, st määratud jada põhjal, lokaalset maksimumi. See ongi monotoonse mängu Mullati tuum, mis on Joonisel 1 tähistatud sinise punktina.

\section{LITERATURE CITED, KIRJANDUS}

1. Owen, G., 1971, Game Theory [Russian translation] Mir. Second Edition (1982), New York London, Academic Press, INC. (LONDON).

2. Mullat, J. E., Monotonic Systems idea, different from all known ideas with the same name, was initially introduced in 1971 in the article of Tallinn Technical University Proceedings, a) Очерки по Обработке Информфции и Функциональному Анализу, Seria A, No. 313, pp. 37-44, http://www.datalaundering.com/download/modular-ru.pdf, and further described in b) "Extremal Subsystems of Monotonic Systems, I,II,III," Automation and Remote Control, 1976, 37, 758-766, 1976, 37, 1286-1294; 1977, 38. 89-96.

http://www.datalaundering.com/download/extrem01-ru.pdf, http://www.datalaundering.com/download/extrem02-ru.pdf, http://www.datalaundering.com/download/extrem03-ru.pdf.

3. Nash John F. Jr., 1950, “The bargaining problem.” Econometrica Vol.18, No.2: 155-162. 